\title{
Investigation of mycoviruses in endophytic and phytopathogenic strains of Colletotrichum from different hosts
}

\author{
P. Rosseto' ${ }^{1}$, A.T. Costa ${ }^{1}$, J.C. Polonio' ${ }^{1}$ A.A. da Silva ${ }^{1}$, J.A. Pamphile ${ }^{1}$ \\ and J.L. Azevedo ${ }^{2}$ \\ ${ }^{1}$ Departamento de Biotecnologia, Genética e Biologia Celular, \\ Universidade Estadual de Maringá, Maringá, PR, Brasil \\ 'Departamento de Genética, Escola Superior de Agricultura "Luiz de Queiroz", \\ Piracicaba, SP, Brasil \\ Corresponding author: J.A. Pamphile \\ E-mail: prof.pamphile@gmail.com \\ Genet. Mol. Res. 15 (1): gmr.15017651 \\ Received September 16, 2015 \\ Accepted November 13, 2015 \\ Published February 26, 2016 \\ DOI http://dx.doi.org/10.4238/gmr.15017651
}

ABSTRACT. Fungi belonging to the Colletotrichum genus can be categorized as endophytic or phytopathogenic. These fungi can be infected by viruses, termed mycoviruses, which are known to promote hypovirulence in infected fungi. However, there are few studies that have described mycoviral infections of endophytes. The production of secondary metabolites by endophytes with antimicrobial potential in inhibiting numerous pathogens has gained increasing attention. The aim of the current study was to investigate the presence of mycoviruses in endophytic and phytopathogenic fungi of the Colletotrichum genus, as well as to analyze the antimicrobial activity of crude extracts obtained from these samples. To detect the presence of mycoviruses in the samples, dsRNA was extracted, treated with enzymes, and analyzed following electrophoresis in agarose gel. Furthermore, isometric mycoviral particles were observed by transmission electron microscopy. Serial microdilution methodology was used to test crude extracts of Colletotrichum spp for antibacterial activity 
against Escherichia coli and Staphylococcus aureus, and antifungal activity against Fusarium solani. The results of the molecular and microscopic analyses indicated that a phytopathogenic strain presented infection by mycovirus. The antibacterial activity analysis revealed that the minimum inhibitory concentrations and minimum bactericidal concentrations were low for the fungal extracts of the two endophytes, indicating that these extracts were effective antibacterial agents. However, their antifungal activity against $F$. solani was not statistically different compared to that of the negative control.

Key words: Mycovirus; Colletotrichum; Crude extracts; Antimicrobial activity; Endophyte; Phytopathogen

\section{INTRODUCTION}

Viruses are infectious agents that can infect almost all living organisms, including fungi. Viruses that infect fungi are termed mycoviruses, most of which have double-stranded RNA (dsRNA) genomes that are packed into non-enveloped isometric particles (Refos et al., 2013).

Mycoviruses have no overt effect on their fungal hosts, although some species can cause changes in the physiology of phytopathogenic fungi, leading to hypovirulence. Hypovirulence is defined as reduced pigmentation, asexual sporulation, loss of fertility, and/or reduced growth rate (van de Sande et al., 2010), leading to a reduction in virulence (Kanematsu et al., 2010), and therefore hypovirulence-associated mycoviruses have described as biological control agents for phytopathogenic fungi (Peever et al., 2000; Ghabrial and Suzuki, 2009; van de Sande et al., 2010). To date, few studies have reported on the presence of mycoviruses in endophytic fungi, the presence of which may be linked with plant adaptation to extreme environments, conferring heat tolerance to plant hosts that contain the endophytes (Márquez et al., 2007; Herrero et al., 2009; Asencio et al., 2013). Different molecular approaches are used for detecting the presence of and identification of mycoviruses. Specifically, the use of transmission electron microscopy (TEM) contributes to the visualization and thus confirmation of mycoviral particles.

Colletotrichum spp have been screened for the presence of mycovirus (Figueirêdo et al., 2012; Lima et al., 2012; Bezerra, 2015). This genus is considered the most widely distributed, and inhabits plants in the endophytic form as well as phytopathogenically. When this fungus acts as an endophyte, it does not cause damage, receives nutrients and plant protection from its host, and in exchange may help the plant under stress conditions through the production of chemical compounds (Petrini, 1991; Azevedo et al., 2000). In contrast, when Colletotrichum acts as a phytopathogen, it causes necrotic lesions, leaf and fruit anthracnose (Freitas, 2014).

Interactions between endophytes and their hosts have emerged as a promising alternative for the production of a vast number of secondary metabolites and enzymes (Firáková et al., 2007; Corrêa et al., 2014). A single endophyte may be able to produce a large variety of bioactive metabolites (Ramasamy et al., 2010), and these metabolites may have antimicrobial potential with efficient inhibitory actions against certain pathogens, thereby enabling the procurement of biotechnological products with low financial and environmental cost.

The aim of the current study was investigate the presence of mycoviruses in endophytic and phytopathogenic strains of the Colletotrichum genus, as well as to analyze the antimicrobial activity of crude extracts obtained from these samples. 


\section{MATERIAL AND METHODS}

\section{Biological material}

Samples of endophytic fungi of the Colletotrichum genus were provided by the Microbial Biotechnology Laboratory at Universidade Estadual de Maringá, Paraná, Brazil, and phytopathogenic strains were provided by Embrapa Grape \& Wine of Bento Gonçalves, Rio Grande do Sul, Brazil (Table 1).

Table 1. Fungal strains along with their fungal plant interactions (endophyte/phytopathogen) and host plants.

\begin{tabular}{|c|c|c|}
\hline Isolate & Interaction with plant & Host \\
\hline Colletotrichum sp 1 & Phytopathogenic & Grape \\
\hline Colletotrichum sp CNPUV 378 & Phytopathogenic & Grape \\
\hline Colletotrichum sp 29b & Endophytic & Coffee \\
\hline Colletotrichum sp 64 & Endophytic & Coffee \\
\hline Colletotrichum sp 60 & Endophytic & Coffee \\
\hline Colletotrichum sp 27 & Endophytic & Coffee \\
\hline Colletotrichum sp 65 & Endophytic & Coffee \\
\hline Colletotrichum sp 153 & Endophytic & Coffee \\
\hline Colletotrichum sp 163 & Endophytic & Coffee \\
\hline Colletotrichum sp 118 & Endophytic & Coffee \\
\hline Colletotrichum sp 137b & Endophytic & Coffee \\
\hline Colletotrichum sp 137a & Endophytic & Coffee \\
\hline Colletotrichum sp 136a & Endophytic & Coffee \\
\hline Colletotrichum sp 173b1 & Endophytic & Coffee \\
\hline Colletotrichum sp 174 & Endophytic & Coffee \\
\hline Colletotrichum sp 176 & Endophytic & Coffee \\
\hline Colletotrichum sp 155 & Endophytic & Coffee \\
\hline Colletotrichum sp 189 & Endophytic & Coffee \\
\hline Colletotrichum sp 11 & Endophytic & Coffee \\
\hline Colletotrichum sp 47 & Endophytic & Coffee \\
\hline Colletotrichum sp 202a & Endophytic & Coffee \\
\hline Colletotrichum sp 149 & Endophytic & Coffee \\
\hline Colletotrichum sp 165b3 & Endophytic & Coffee \\
\hline Colletotrichum sp 167 & Endophytic & Coffee \\
\hline Colletotrichum sp 110 & Endophytic & Coffee \\
\hline Colletotrichum sp 61 & Endophytic & Coffee \\
\hline
\end{tabular}

\section{Extraction of total nucleic acids of Colletrotrichum spp}

Fungal strains were grown for seven days on Petri dishes containing potato dextrose agar (PDA) medium (Smith and Onions 1983 ) at $28^{\circ} \mathrm{C}$. Next, the mycelia were removed from the dishes and ground to a fine powder with liquid nitrogen. Total nucleic acids were extracted as described by Raeder and Broda (1985).

\section{Extraction of dsRNA}

dsRNA was extracted using methods described by Morris and Dodds (1979) with modifications. Cellulose columns (CF-11, Whatman International Ltd., Kent, England) for chromatography were set up in disposable 10-mL syringes, with $2 \mathrm{~g}$ microgranular cellulose. The columns were buffered with successive washes with 1X STE buffer ( $25 \mathrm{mM}$ Tris-HCl, pH 7.5, 50 $\mathrm{mM} \mathrm{NaCl}$, and $0.5 \mathrm{mM}$ EDTA) containing $16 \%(\mathrm{v} / \mathrm{v})$ ethanol to remove DNA and single-stranded RNA. The putative dsRNA that remained in the column was eluted with STE without ethanol, and precipitated with the addition of 0.1 volume of $3 \mathrm{M}$ sodium acetate and $20 \mathrm{~mL}$ ice cold absolute 
ethanol. The precipitate was collected by centrifugation at 10,000 $\mathrm{g}$ for $25 \mathrm{~min}$. The supernatant was discarded, and the precipitate was washed with $70 \%$ ethanol and centrifuged. The supernatant was discarded, and the pellet was dried and resuspended in diethylpyrocarbonate water. The dsRNA was analyzed following $1.5 \%$ agarose gel electrophoresis.

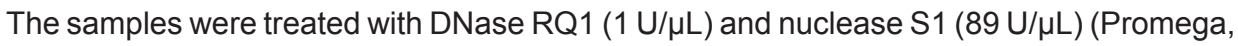
Madison, WI, USA). DNase RQ1 digestion was performed at $37^{\circ} \mathrm{C}$ for $30 \mathrm{~min}$, followed by incubation at $65^{\circ} \mathrm{C}$ for $10 \mathrm{~min}$ to inactivate the enzyme. Nuclease $\mathrm{S} 1$ digestion was performed at $37^{\circ} \mathrm{C}$ for 30 $\min$. The efficiency of treatments was analyzed by agarose gel electrophoresis.

\section{TEM}

TEM was used as described by Figueirêdo et al. (2012). Briefly, hyphae and spores of fungi grown in PDA medium were carefully removed with a glass slide, transferred to a mortar containing $0.2 \mathrm{~mL} 0.05 \mathrm{M}$ cacodylate buffer, $\mathrm{pH} 7.2$, and macerated with pestle. Small drops of this material were placed on a parafilm sheet, on top of which carbon-coated 300 mesh grids were floated for $20 \mathrm{~min}$. The grids were removed, and excess liquid was absorbed with a piece of filter paper. The grids were washed with drops of distilled water, and then floated on a droplet of $1 \%$ aqueous uranyl acetate for $15 \mathrm{~min}$. After removal of excess liquid, the grids were dried and examined with a Zeiss EM 900 TEM with digital image recording.

\section{Crude fungal extract isolation for analysis of antimicrobial activity}

The extraction of metabolites was performed according to methods described by Rukachaisirikul et al. (2008) with modifications. Two endophytic strains (29b and 64) and one phytopathogenic strain (2) were randomly selected to obtain crude extracts. Pure cultures of fungi were re-cultured on Petri dishes with PDA at $28^{\circ} \mathrm{C}$ for seven days to obtain young colonies. Three mycelia fragments $\left(5 \mathrm{~mm}^{2}\right)$ of each fungus were inoculated into $2 \mathrm{~L}$ Erlenmeyer flasks containing $1 \mathrm{~L}$ potato dextrose broth and incubated at $28^{\circ} \mathrm{C}$ for 30 days under stationary conditions. The broth cultures were filtered and centrifuged at $5300 \mathrm{~g}$ for $15 \mathrm{~min}$ to separate the culture broth and mycelia. All filtrates were extracted three times with equal volumes of ethyl acetate in a separatory funnel, where the separation of phases occurred by polarity difference after strong agitation. The acetate phase was separated, dried with anhydrous sodium sulfate, and then concentrated in a rotary evaporator at $38^{\circ} \mathrm{C}$. The extract residues were resuspended in $10 \mathrm{~mL}$ absolute methanol and stored at $4^{\circ} \mathrm{C}$.

\section{Antibacterial activity analysis of the crude fungal extracts}

The minimum inhibitory concentration (MIC) and minimum bactericidal concentration (MBC) were evaluated for the crude extracts obtained from two fungal strains (29b and 64) against the bacteria Escherichia coli (ATCC 25922) and Staphylococcus aureus (ATCC 25923) from the collection at Universidade Estadual de Maringá Microbiology Laboratory. For these evaluations, a serial microdilution method was used on 96-well microplates as recommended by the CLSI M7-A9 (2012). The concentrations of the extracts ranged from 2.7 to $87.5 \mu \mathrm{g} / \mathrm{mL}$. Tetracycline was used as positive control for both bacteria at a concentration ranging from 0.48 to $62.5 \mu \mathrm{g} / \mathrm{mL}$. Bacterial microcultivation in culture medium without the evaluated crude extracts served as a negative control. All tests were performed in triplicate. Mueller Hinton medium (100 $\mu \mathrm{L})$ was added to each 
well of the microplates. The crude extracts were diluted in 5\% dimethylsulfoxide, and then $100 \mu \mathrm{L}$ diluted crude extracts was added into the first well to start the serial microdilution at a ratio of 1:2. At the end of microdilution, $5 \mu \mathrm{L}$ of the previously prepared bacterial inoculum was added, with a subsequent 1:10 dilution, resulting in a final concentration of inoculum in each well of $10^{5} \mathrm{UFC} / \mathrm{mL}$. The plates were then incubated for $24 \mathrm{~h}$ at $35^{\circ} \mathrm{C}$. For evaluation of the $\mathrm{MBC}$, a microcultivation in $10 \mu \mathrm{L}$ Mueller Hinton agar was performed for $24 \mathrm{~h}$ at $35^{\circ} \mathrm{C}$ after the initial microplate incubation period. The MBC was defined as the lowest concentration of extract that was able to kill all bacteria after the treatment period. After microcultivation, the colonies were counted using the negative control as the baseline parameter, as the number of colonies is related to the total reduction in bacterial load, which was calculated as bacterial load reduction $=\log (\mathrm{CFU} / \mathrm{mL})$.

\section{Antifungal activity analysis of the crude fungal extract}

The crude extracts obtained from the $29 \mathrm{~b}$ and 64 fungal isolates were tested against the phytopathogenic fungus Fusarium solani, which was provided by the Microorganisms IGSALQ collection from the Laboratory João Lucio de Azevedo, ESALQ, Universidade de São Paulo, Brazil (www.cria.org.br/cgee/junho/docs/cadastro_colecoes.xls). Mycelial fragments from the phytopathogenic colony were inoculated onto Petri dishes with PDA medium $4 \mathrm{~cm}$ away from filter paper disks $(5 \mathrm{~mm})$. The crude extracts $(10 \mu \mathrm{L})$ of the endophytic strains were applied to the filter paper at a concentration of $700 \mu \mathrm{g} / \mathrm{mL}$. Benlate fungicide $(700 \mu \mathrm{g} / \mathrm{mL})$ served as the positive control, and methanol $(\mathrm{MeOH})$ was used as the solvent control. The inhibition rate was evaluated with the ImageJ software, in which the mycelial growth area of the phytopathogen with the crude extracts was compared with that of controls. The index of inhibition percent was calculated as $1 \mathrm{~m} \%$ $=(1-\mathrm{TM} / \mathrm{CM}) \times 100$, where $\mathrm{Im} \%=$ inhibition index in percentage of growth, $\mathrm{TM}=$ mean of the area for treatments in $\mathrm{cm}^{2}$, and $\mathrm{CM}=$ mean of the area for controls in $\mathrm{cm}^{2}$.

\section{Statistical analysis}

All statistical analyses were performed with the Sisvar 5.4 software. The Scott Knott test was used by which $\mathrm{P}<0.05$ was considered statistically significant.

\section{RESULTS}

\section{Detection and visualization of mycovirus}

Among the Colletrotrichum isolates analyzed, the following nine samples presented nucleic acid bands that suggested the possible presence of mycovirus from total nucleic acid extractions: 29b, 47, 61, 136a, 149, 153, 173b1, 174, and CNPUV 378 (data not shown). Based on these results, dsRNA isolation was performed on these nine isolates, and the dsRNA was further subjected to enzyme treatments with DNase RQ1 and nuclease S1. The electrophoretic analysis of the enzyme cleaved dsRNA revealed bands potentially associated with mycovirus only in Colletotrichum sp CNPUV 378.

For CNPUV 378, we observed two fragments with sizes corresponding to approximately 1500 and 2500 base pairs (bp) following agarose gel electrophoresis (Figure 1). The samples subjected to dsRNA extraction were then analyzed by TEM. The microscopy results revealed the presence of isometric virus particles measuring between 25 and $50 \mathrm{~nm}$ in diameter (Figure 2), with 
and without genetic material, in CNPUV 378, which was in agreement with the data obtained by molecular analysis.

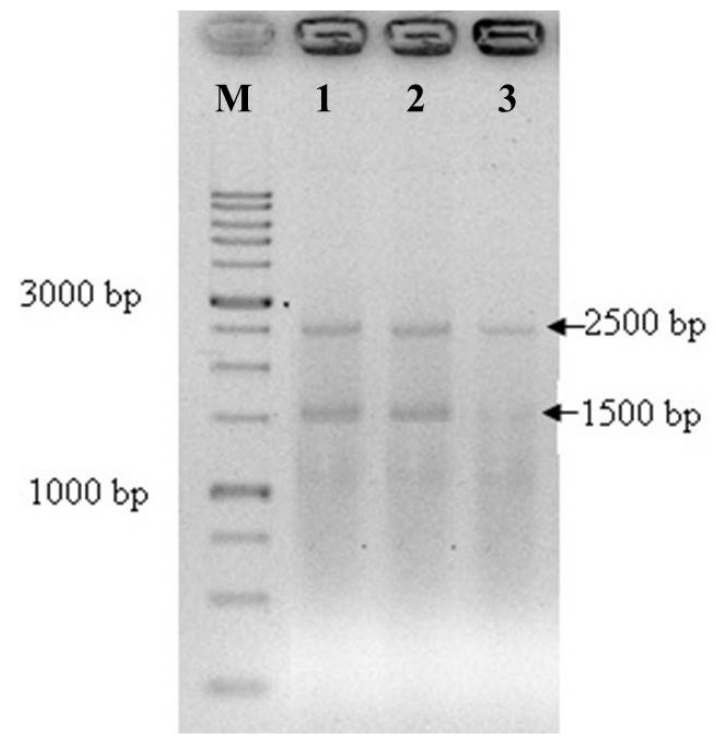

Figure 1. Bands of double-stranded RNA from Colletotrichum isolates visualized following agarose gel electrophoresis. Lane $M=1-\mathrm{kb}$ DNA ladder; lane 1 = dsRNA extracted from phytopathogenic isolate CNPUV 378; lanes 2 and $3=$ treatment of the dsRNA from lane 1 with the DNAse RQ1 and nuclease S1 enzymes, respectively.

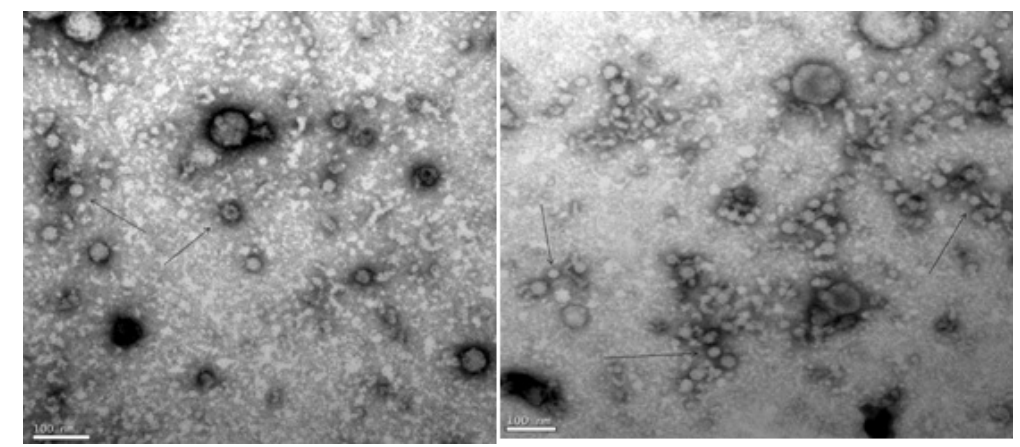

Figure 2. Transmission electron microscopy image of isometric mycovirus particles with diameters between 25 and 50 $\mathrm{nm}$ from the Colletotrichum phytopathogenic strain. Bar $=100 \mathrm{~nm}$.

\section{Antibacterial activity of the crude extracts}

The results of the antibacterial activity assessment of the of crude fungal extracts, including the MICs and MBCs of the endophytic/phytopathogenic fungi are presented in Table 2.

The crude extract of the Colletotrichum sp 64 endophytic strain against $E$. coli exhibited the same MIC and MBC bacteriostatic and bactericidal activity at a concentration of $10.94 \mu \mathrm{g} / \mathrm{mL}$, with bacterial load reduction of 10 . The MIC and MBC of the Colletotrichum sp 64 extract against S. aureus was 2.7 and $5.5 \mu \mathrm{g} / \mathrm{mL}$, respectively, with a bacterial load reduction of 4.4 . 
E. coli and S. aureus treated with the crude extract of the Colletotrichum sp $29 \mathrm{~b}$ endophytic strain revealed the same $\mathrm{MBC}$ able to remove all bacterial cells, which was $43.7 \mu \mathrm{g} / \mathrm{mL}$. However, the MIC value for the Colletotrichum sp $29 \mathrm{~b}$ extract was better against $S$. aureus $(5.5 \mu \mathrm{g} / \mathrm{mL})$ than that against $E$. coli $(21.9 \mu \mathrm{g} / \mathrm{mL})$ with bacterial load reductions against $S$. aureus and $E$. coli of 4.7 and 6.5, respectively. Comparatively, Colletotrichum sp CNPUV 378 extract had MIC and MBC values against $E$. coli of 43.7 and $87.5 \mu \mathrm{g} / \mathrm{mL}$, respectively, with a bacterial load reduction of 6 . The extract of this phytopathogenic fungus had MIC and MBC values against S. aureus of 21.9 and $43.7 \mu \mathrm{g} / \mathrm{mL}$, respectively, with a bacterial load reduction of 4 . Together, these results indicate that compared to the other extracts, the crude extract of Colletotrichum sp 64 was the most efficient antibacterial agent against both E. coli and S. aureus.

Table 2. Antibacterial activity of crude extracts from Colletotrichum sp endophytic strains (29b and 64), from Colletotrichum gloeosporioides phytopathogenic strain (CNPUV 378), and tetracycline against of Escherichia coli and Staphylococcus aureus.

\begin{tabular}{l|c|c|c|c|c|c}
\hline \multirow{2}{*}{ Antibacterial treatment } & \multicolumn{2}{|c|}{ E. coli } & \multicolumn{3}{c}{ S. aureus } \\
\cline { 2 - 8 } & $\mathrm{MIC}^{1}$ & $\mathrm{MBC}^{1}$ & Bacterial load reduction $^{2}$ & MIC & MBC & Reduction \\
\hline Colletotrichum sp 64 & 10.94 & 10.94 & 10 & 2.7 & 5.5 & 4.4 \\
\hline Colletotrichum sp 29b & 21.9 & 43.7 & 6.5 & 5.5 & 43.7 & 4.7 \\
\hline Colletotrichum sp CNPUV 378 & 43.7 & 87.5 & 6 & 21.9 & 43.7 & 4 \\
\hline Tetracycline & 1.95 & 62.5 & ${ }^{*}$ & 0.48 & 7.71 & ${ }^{*}$ \\
\hline
\end{tabular}

${ }^{1}$ Concentration in $\mu \mathrm{g} / \mathrm{mL} .{ }^{2}$ Bacterial load reduction $=\log (\mathrm{CFU} / \mathrm{mL})$. *Not calculated.

\section{Antifungal activity of the crude extracts}

The antifungal activity analysis revealed that the activity against $F$. solani of the crude extracts of Colletotrichum spp 64 and 29b did not differ statistically from that of the negative control treatment with methanol, indicating that these extracts weren't effective antifungal agents (Table 3). Although the extracts tested herein did not work effectively against $F$. solani, there are many reports showing that endophyte extracts may inhibit various pathogenic microorganisms (Assakura et al., 2009; Ramos et al., 2010; Orlandelli et al., 2012; Rhoden et al., 2012; Bezerra, 2015). Therefore, these extracts may be effective in the inhibition other phytopathogens.

Table 3. Antifungal activity of the crude extracts from Colletotrichum spp against Fusarium solani.

\begin{tabular}{l|c|c}
\hline Treatment & Mycelial growth area $\left(\mathrm{cm}^{2}\right)^{1}$ & $1 \mathrm{~m} \%$ \\
\hline Colletotrichum sp 29b & $38.01^{\mathrm{b}}$ & 7.52 \\
\hline Colletotrichum sp 64 & $40.42^{\mathrm{b}}$ & 1.65 \\
\hline Positive control & $33.82^{\mathrm{a}}$ & 17.71 \\
\hline Negative control & $41.10^{\mathrm{b}}$ & 0 \\
\hline
\end{tabular}

${ }^{1}$ Mean mycelial growth area in $\mathrm{cm}^{2}$; ${ }^{2}$ value was significantly different from the negative control by the Scott Knott test $(P<0.05)$; ${ }^{b}$ values were not statistically different by the Scott Knott test $(P>0.05)$.

\section{DISCUSSION}

The molecular and microscopic analyses suggest that the mycovirus detected herein may belong to the family Partitiviridae, due to the number and size of fragments visualized on the agarose gel, and the particle size observed by TEM. Partitiviruses possess two essential dsRNA genome segments ranging from 1300 to $2500 \mathrm{bp}$ in length with one long open reading frame on one of the RNA strands. Partitivirus particles are isometric, with diameters of different strains ranging from 25 to $40 \mathrm{~nm}$ as determined by negative stain electron microscopy (Nibert et al., 2014). 
In recent years, the number of studies regarding mycoviruses in phytopathogenic fungi has increased considerably (Figueirêdo et al., 2012; Zhong et al., 2014; Özkan and Coutts, 2015; Shang et al., 2015). The frequency of mycovirus strains in Colletotrichum from different plant hosts as detected by mycoviral dsRNA herein was low $(1 / 26 ; 3.85 \%)$. Similarly, in a study of different strains of endophytic fungi from the Colletotrichum genus, Lima et al. (2012) detected dsRNA in only three isolates from a total of thirty-nine $(7.7 \%)$ analyzed.

In the molecular analysis of endophytic fungi, we could not confirm the absence of mycovirus in the majority of samples analyzed. This is due to the methodology used in this study, where we sought to detect dsRNA because the majority of mycoviruses have dsRNA genomes, although it is possible that some mycoviruses present in endophytic fungi may contain single-stranded RNA or DNA genomes. Moreover, the absence of visualization of viral particles with microscopy also does not necessarily signify the absence of mycovirus in endophytic fungal samples. As described by Nuss (2005), this may be because various mycoviruses do not encode proteins that form capsids, and rather exist as nude molecules of dsRNA. Thus, uranyl acetate will fail to stain the viral protein, making it impossible to visualize virus particles. In this case, the detection mycoviruses may be achieved by metagenomic analysis (Al Rwahnih et al., 2011).

Some dsRNA mycoviruses are characterized as beneficial, because they can be used as biological control agents of certain fungi that cause diseases in cultivated plants. Since these viruses can be transmitted via hyphal anastomosis, infected fungi can naturally transmit the virus to healthy fungi, which can cause hypovirulence. Dalzoto et al. (2006) analyzed the hypovirulence associated with mycoviral dsRNA in Beauveria bassiana. It was demonstrated that dsRNA in $B$. bassiana strains was responsible for hypovirulence effects against Euschistus heros, when compared with isogenic dsRNA-free strains. This study indicated that hypovirulence may be an important tool in agriculture as a biocontrol.

Zhong et al. (2014) observed spherical virus particles of approximately $40 \mathrm{~nm}$ in diameter via TEM, and moreover, after nucleic acid extraction from a mycelial preparation of a Colletotrichum acutatum HNZJ001 isolated from an anthracnose lesion on immature pepper fruit, two dsRNA bands were observed following gel electrophoresis. Genome comparison and phylogenetic analysis indicated that the virus was of the family Partitiviridae. These results suggested the presence of a novel twosegment dsRNA virus termed Colletotrichum acutatum partitivirus 1. Figueirêdo et al. (2012) reported the detection of a mycovirus in a strain of Colletotrichum gloeosporioides causing anthracnose in cashew trees. TEM revealed the presence of isometric particles (30-35 nm in diameter), confirming that the infection of this C. gloeosporioides strain was by a mycovirus. More recently, mycovirus research has begun to utilize new technology (Pearson et al., 2009), including next generation sequencing and bioinformatics, which has made it more feasible to use whole genome or metagenomic approaches to screen fungi for the presence of potential viruses (Mokili et al., 2012).

The results of the antimicrobial activity analyses stand out in the present study, which highlight the potential of using the extracts of endophytes as alternatives for biocontrol (Orlandelli et al., 2012; Rhoden et al., 2012). For example, as a bactericidal agent, the crude extract of Colletotrichum sp 64 was effective in inhibition and elimination of E. coli and S. aureus, with a bacterial load reduction of 10.0 for $E$. coli and 4.4 for $S$. aureus. This data provides strong evidence that the metabolites of this fungus are a potential source of new antibiotics. Similarly, Arivudainambi et al. (2011) isolated the endophytic fungus C. gloeosporioides from the medicinal plant Vitex negundo L., and its extracts were screened for their antibacterial activity against methicillin-, penicillin-, and vancomycin-resistant clinical strains of $S$. aureus. The results showed that the antimicrobial metabolites of the endophytic fungus in combination with antibiotics were able to 
substantially decrease the MIC of antibiotics against a diverse group of bacteria containing genetic elements responsible for drug resistance. Specifically, the extract showed effective antibacterial activity against $S$. aureus strain 9 , with a MIC of $31.25 \mu \mathrm{g} / \mathrm{mL}$.

Souza et al. (2004), isolated Colletotrichum sp, Guignardia sp, Aspergillus niger, Phomopsis sp, and Xylaria sp endophytic fungi from Palicourea longiflora and Strychnos cogen, which are toxic plants from the Amazon. The authors then tested these fungi against pathogenic bacteria, and found that two Colletotrichum sp strains had antibacterial activity against $S$. aureus, Bacillus sp and $B$. subtilis.

Silva (2013), isolated endophytic fungi from healthy leaves of Schinus terebinthifolius Raddi (mastic-red), and evaluated fungal extracts for their antimicrobial activity against pathogenic microorganisms. Particularly, the antimicrobial activity was evaluated, and it was found that the $\mathrm{MIC}$ and $\mathrm{MBC}$ against $S$. aureus were 125 and $250 \mu \mathrm{g} / \mathrm{mL}$, respectively, and against $E$. coli, the MIC and MBC were 500 and $1000 \mu \mathrm{g} / \mathrm{mL}$, respectively.

Ramos et al. (2010), obtained crude extracts from Papulaspora immersa and Arthrinium state endophytic fungi isolated from the roots of Smallanthus sonchifolius (yacón), and investigated the ability of these extracts to inhibit S. aureus, Kocuria rhizophila, Pseudomonas aeruginosa, and E. coli. The MIC of the extract of $P$. immersa against $P$. aeruginosa was $90 \mu \mathrm{g} / \mathrm{mL}$, and the extracts of $A$. state from $A$. montagnei Sacc. against ATCC bacteria had the best result against $P$. aeruginosa $(\mathrm{MIC}=160 \mu \mathrm{g} / \mathrm{mL})$.

Meng et al. (2015), isolated and identified five new compounds from the culture extract of Penicillium brocae MA-231, an endophytic fungus isolated from the fresh tissue of the marine mangrove plant Avicennia marina. All of these compounds were examined for antimicrobial activities against $S$. aureus and Gaeumannomyces graminis. The screening results showed that the MIC values ranged from 0.25 to $32.0 \mu \mathrm{g} / \mathrm{mL}$ and 0.25 to $64 \mu \mathrm{g} / \mathrm{mL}$, respectively, against the tested strains.

Assakura et al. (2009) obtained metabolite extracts of an endophytic fungus isolated from Trichilia elegans, which were tested against Colletotrichum sp and Moniliophthora perniciosa phytopathogens. The results showed that against Colletotrichum sp, there was no significant inhibition by the secondary metabolites of the endophyte.

In the present study, the presence of mycovirus particles was detected molecularly and by TEM in a Colletotrichum grape phytopathogenic strain, but was not observed in the isolates from Colletotrichum coffee endophytic strains. The antibacterial activity analysis revealed that low concentrations of secondary metabolites from extracts of fungi of the genus Colletotrichum are effective for use against pathogenic bacteria. However, the extracts tested herein were not significantly effective against a representative phytopathogen.

\section{Conflicts of interest}

The authors declare no conflict of interest.

\section{ACKNOWLEDGMENTS}

We would like to thank Embrapa Uva \& Vinho for the phytopathogenic strains; the Núcleo de Apoio à Pesquisa em Microscopia Eletrônica Aplicada à Agricultura (NAP/MEPA) ESALQ/ USP for the availability and use of the electronic transmission microscope; and the Microbiology Laboratory of UEM. We also thank Coordenação de Aperfeiçoamento de Pessoal de Nível Superior (CAPES) for the Master's scholarship for P. Rosseto and the CAPES/PNPD-UEM postdoctoral 
scholarship. Research supported by CNPq (\#311534/2014-7 and \#447265/2014-8) and Fundação Araucária (\#276/2014).

\section{REFERENCES}

Al Rwahnih M, Daubert S, Urbez-Torres JR, Cordero F, et al. (2011). Deep sequencing evidence from single grapevine plants reveals a virome dominated by mycoviruses. Arch. Virol. 156: 397-403. http://dx.doi.org/10.1007/s00705-010-0869-8

Arivudainambi US, Anand TD, Shanmugaiah V, Karunakaran C, et al. (2011). Novel bioactive metabolites producing endophytic fungus Colletotrichum gloeosporioides against multidrug-resistant Staphylococcus aureus. FEMS Immunol. Med. Microbiol. 61: 340-345. http://dx.doi.org/10.1111/j.1574-695X.2011.00780.x

Asencio NH, Máquez SS and Zabalgogeazcoa I (2013). Mycovirus effect on the endophytic establishment of the entomopathogenic fungus Tolypocladium cylindrosporum in tomato and bean plants. BioControl 58: 225-232. http:// dx.doi.org/10.1007/s10526-012-9476-9

Assakura AH, Orlandelli RC, Alberto RN, Rhoden SA, et al. (2009). Obtenção de metabolitos do fungo endofítico -10.1 .2$ isolado de Trichilia elegans e seu uso potencial no controle de fitopatógenos. V EPCC - Encontro Nacional de Produção Cientifica Cesumar.

Azevedo JL, Maccheroni WJ, Pereira JO and Araujo WJ (2000). Endophytic microorganisms: a review on insect control and recent advances on tropical plants. Electron. J. Biotechnol. 3: 40-65. http://dx.doi.org/10.2225/vol3-issue1-fulltext-4

Bezerra TE (2015). Potencial biotecnológico dos fungos endofíticos do guaraná (Paullinia cupana var. sorbilis) no controle biológico da antracnose. Tese de doutorado, PP - Multidisciplinar em Biotecnologia, Universidade Federal do Amazonas, Manaus.

Clinical \& Laboratory Standards Institute (CLSI) (2012). Methods for Diluition Antimicrobial Susceptibity Tests for Bacteria that Grow Aerobically. 9th edn. Approved Stardard. CLSI Document M7-A9. Wayne, PA.

Corrêa RC, Rhoden SA, Mota TR, Azevedo JL, et al. (2014). Endophytic fungi: expanding the arsenal of industrial enzyme producers. J. Ind. Microbiol. Biotechnol. 41: 1467-1478. http://dx.doi.org/10.1007/s10295-014-1496-2

Dalzoto PR, Glienke-Blanco C, Kava-Cordeiro V, Ribeiro JZ, et al. (2006). Horizontal transfer and hypovirulence associated with double-stranded RNA in Beauveria bassiana. Mycol. Res. 110: 1475-1481. http://dx.doi.org/10.1016/j.mycres.2006.08.009

Figueirêdo LC, Figueiredo GS, Giancoli ACH, Tanaka FAO, et al. (2012). Detection of isometric, dsRNA-containing viral particles in Colletotrichum gloeosporioides isolated from cashew tree. Trop. Plant Pathol. 37: 142-145. http://dx.doi. org/10.1590/S1982-56762012000200007

Firáková S, Sturdiková M and Múcková M (2007). Bioactive secondary metabolites produced by microorganisms associated with plants. Biologia 62: 251-257. http://dx.doi.org/10.2478/s11756-007-0044-1

Freitas MLO (2014). Etiologia, Inoculação e Escala Diagramática no Patossistema (Colletotrichum spp) x Cafeeiro. Master's thesis, Universidade Federal de Lavras, Lavras.

Ghabrial SA and Suzuki N (2009). Viruses of plant pathogenic fungi. Annu. Rev. Phytopathol. 47: 353-384. http://dx.doi. org/10.1146/annurev-phyto-080508-081932

Herrero N, Sánchez Márquez S and Zabalgogeazcoa I (2009). Mycoviruses are common among different species of endophytic fungi of grasses. Arch. Virol. 154: 327-330. http://dx.doi.org/10.1007/s00705-008-0293-5

Kanematsu S, Sasaki A, Onoue M, Oikawa Y, et al. (2010). Extending the fungal host range of a partitivirus and a mycoreovirus from Rosellinia necatrix by inoculation of protoplasts with virus particles. Phytopathology 100: 922-930. http://dx.doi. org/10.1094/PHYTO-100-9-0922

Lima JS, Figueirêdo JG, Gomes RG, Stringari D, et al. (2012). Genetic diversity of Colletotrichum spp an endophytic fungi in a medicinal plant, Brazilian pepper tree. ISRN Microbiol. 2012: 215716. http://dx.doi.org/10.5402/2012/215716

Márquez LM, Redman RS, Rodriguez RJ and Roossinck MJA (2007). A virus in a fungus in a plant: three-way symbiosis required for thermal tolerance. Science 315: 513-515. http://dx.doi.org/10.1126/science.1136237

Meng LH, Zhang P, Li XM and Wang BG (2015). Penicibrocazines A-E, five new sulfide diketopiperazines from the marinederived endophytic fungus Penicillium brocae. Mar. Drugs 13: 276-287. http://dx.doi.org/10.3390/md13010276

Mokili JL, Rohwer F and Dutilh BE (2012). Metagenomics and future perspectives in virus discovery. Curr. Opin. Virol. 2: 63-77. http://dx.doi.org/10.1016/j.coviro.2011.12.004

Morris TJ and Dodds JA (1979). Isolation and analysis of Double-stranded RNA from vírus infected plant and fungal tissue. Phytopathology 69: 854-858. http://dx.doi.org/10.1094/Phyto-69-854

Nibert ML, Ghabrial SA, Maiss E, Lesker T, et al. (2014). Taxonomic reorganization of family Partitiviridae and other recent progress in partitivirus research. Virus Res. 188: 128-141.http://dx.doi.org/10.1016/j.virusres.2014.04.007

Nuss DL (2005). Hypovirulence: mycoviruses at the fungal-plant interface. Nat. Rev. Microbiol. 3: 632-642. http://dx.doi. org/10.1038/nrmicro1206 
Orlandelli RC, Alberto RN, Almeida TT, Azevedo JL, et al. (2012). In vitro antibacterial activity of crude extracts produced by endophytic fungi isolated from Piper hispidum Sw. J. Appl. Pharm. Sci. 2: 137-141.

Özkan S and Coutts RHA (2015). Aspergillus fumigatus mycovirus causes mild hypervirulent effect on pathogenicity when tested on Galleria mellonella. Fungal Genet. Biol. 76: 20-26. http://dx.doi.org/10.1016/j.fgb.2015.01.003

Pearson MN, Beever RE, Boine B and Arthur K (2009). Mycoviruses of filamentous fungi and their relevance to plant pathology. Mol. Plant Pathol. 10: 115-128. http://dx.doi.org/10.1111/j.1364-3703.2008.00503.x

Peever TL, Liu YC, Cortesi P and Milgroom MG (2000). Variation in tolerance and virulence in the chestnut blight fungushypovirus interaction. Appl. Environ. Microbiol. 66: 4863-4869. http://dx.doi.org/10.1128/AEM.66.11.4863-4869.2000

Petrini O (1991). Fungal endophytic of tree leaves. In: Microbial ecology of leaves (Andrews J and Hirano SS, eds.). SpringerVerlag, New York, 179-197.

Raeder U and Broda P (1985). Rapid preparation of DNA from filamentous fungi. Lett. Appl. Microbiol. 1: 17-20. http://dx.doi. org/10.1111/j.1472-765X.1985.tb01479.x

Ramasamy K, Lim SM, Abu Bakar H, Ismail N, et al. (2010). Antimicrobial and cytotoxic activities of Malaysian endophytes. Phytother. Res. 24: 640-643. http://dx.doi.org/10.1002/ptr.2891

Ramos HP, Braum GH, Pupo MT and Said S (2010). Antimicrobial activity from endophytic fungi Arthrinium state of Apiospora montagnei Sacc. and Papulaspora immersa. Braz. Arch. Biol. Technol. 53: 629-632. http://dx.doi.org/10.1590/S1516$\underline{89132010000300017}$

Refos JM, Vonk AG, Eadie K, Lo-Ten-Foe JR, et al. (2013). Double-stranded RNA mycovirus infection of Aspergillus fumigatus is not dependent on the genetic make-up of the host. PLoS One 8: e77381. http://dx.doi.org/10.1371/journal.pone.0077381

Rhoden SA, Garcia A, Bongiorno VA, Azevedo JL, et al. (2012). Antimicrobial activity of crude extracts of endophytic fungi isolated from medicinal plant Trichilia elegans A. Juss. J. Appl. Pharm. Sci. 2: 57-59.

Rukachaisirikul V, Sommart U, Phongpaichit S, Sakayaroj J, et al. (2008). Metabolites from the endophytic fungus Phomopsis sp. PSU-D15. Phytochemistry 69: 783-787. http://dx.doi.org/10.1016/j.phytochem.2007.09.006

Silva GBPG (2013) Micro-organismos endofiticos de schinus terebinthifolius raddi (aroeira-vermelha): isolamento, atividade antimicrobiana e prospecção química. Master's thesis, Universidade Federal de Pernambuco.

Shang $\mathrm{HH}$, Zhong J, Zhang RJ, Chen CY, et al. (2015). Genome sequence of a novel endornavirus from the phytopathogenic fungus Alternaria brassicicola. Arch. Virol. 160: 1827-1830. http://dx.doi.org/10.1007/s00705-015-2426-y

Smith D and Onions AHS (1983). The Preservation and Maintenance of Living Fungi. Commonwealth Mycological Institute, Kew.

Souza AQL, Souza ADL, Astolfi Filho S, Belém Pinheiro ML, et al. (2004). Atividade antimicrobiana de fungos endofíticos isolados de plantas tóxicas da amazônia: Palicourea longiflora (Aubl.) rich e Strychnos cogens Bentham. Acta Amazonica 34: 185-195.

van de Sande WW, Lo-Ten-Foe JR, van Belkum A, Netea MG, et al. (2010). Mycoviruses: future therapeutic agents of invasive fungal infections in humans? Eur. J. Clin. Microbiol. Infect. Dis. 29: 755-763. http://dx.doi.org/10.1007/s10096-010-0946-7

Zhong J, Chen D, Lei XH, Zhu HJ, et al. (2014). Detection and characterization of a novel Gammapartitivirus in the phytopathogenic fungus Colletotrichum acutatum strain HNZJ001. Virus Res. 190: 104-109. http://dx.doi.org/10.1016/j. virusres.2014.05.028 